\title{
THE ENVIRONMENTAL CONTENTS OF THE RIGHT TO HIGHER EDUCATION
}

\section{Tymoshenko M., Sukhodolska A.}

\section{INTRODUCTION}

In the modern globalized world the higher education acts as a social agent, demonstrating the close interconnection of the personal and social components of the human civilization development ${ }^{1}$. After all, the modernization of social and state development at the present stage is inseparable from the provision of comprehensive development of personality, which, in turn, is impossible without obtaining by the person the educational level for functioning in modern society ${ }^{2}$. It is during the realization of this right a person joins the process of acquiring knowledge, skills, information, that is, providing access to the spiritual and cultural values of human civilization, forming a system of professional adaptation and knowledge for participation in the system of interaction "social production - environment" on the basis of human values, one of the most important of which is the conservation of nature for present and future generations. Such access to values is the most important social need for each person ${ }^{3}$, the satisfaction of which contributes to the creation of favorable ecological and decent economic and social conditions for human and citizen life in not only environmentally safe but also eco-friendly.

At the same time, the realization of such right implies the organization and operation of a network of educational institutions designed to provide educational services to a person at all levels and stages of education. In turn, the process of providing such services must be objective, deriving from science, systematic and further in nature, from lower (pre-school) to higher (higher education) level.

\section{Theoretical and legal content of the right to higher education}

The right to education is under the obligation of the state to provide at least a minimum guarantee to ensure both the accessibility of educational

\footnotetext{
${ }^{1}$ Podolska E. Education in the context of globalization: directions and mechanisms of reform implementation in Ukraine. Higher school, 2007, № 1, pp. 48-55.

${ }^{2}$ Bell D. The Future Post-Industrial Society: The Experience of Social Forecasting. Moscow: Academia, 1999, $783 \mathrm{p}$.

${ }^{3}$ Kostenko O. Culture and Legal - Countering Evil: A Monograph, Kiev: Attica, 2008, $352 \mathrm{p}$.
} 
services within the functioning of the relevant network of educational institutions and the provision of systematic professional knowledge that would take into account the environmental component. Constitutional regulation of higher education and its environmental and ecological and legal components, appropriate programming of the legal consolidation of this brunch of social relations is an objective reflection of the general public significance and functional properties of the phenomenon of higher education for the personality development, society and state development, the embodiment of social value conditions of the globalized civilization development, accompanied by an increase in environmental challenges and threats.

It is about the right to education corresponds not only to the obligation of the state to create state-owned educational establishments and to provide conditions for the establishment and functioning of public and private higher educational institutions on an equal basis ${ }^{4}$. The state ensures the proper functioning of higher education institutions, which should provide the necessary environmental knowledge to specialists in various fields of activity through a system of regulatory, registration, licensing, control and certification measures.

Therefore, the constitutional and legal consolidation of the right to education and forms of its implementation through the higher educational institution activity as an organizational unit activity aims to promote the realization of the human right to higher education as an element of the subjective is key to the constituting the initial principles of the legal regulation of the economic activity of higher educational institutions as well as the right to education in general and the right to obtain professional environmental knowledge necessary for the performance of professional responsibilities in particular. That is, it is about the implementation of the famous scientist prof. V. Kostytskyy proposal on the adoption of the Law of Ukraine "On Environmental Education". His project was developed under his guidance in 1991. In this case, it would also mean introducing an environmental and environmental and legal minimum level of knowledge in the higher education system, and establishing a minimum level of environmental and environmental and legal knowledge in addressing issues related to the hiring and promotion ${ }^{5}$.

\footnotetext{
${ }^{4}$ Shapoval R. The human and citizen constitutional right to education in Ukraine. URl: www.nbuv.gov.ua/portal/soc_gum/pib/2011_1/PB-1/PB-1_5.pdf.; Bonyak V. The human and citizen constitutional right to education and its support in Ukraine: dis. ... Cand. lawyer. Sciences: 12.00.02 / V.O. Bonyak; Nat. Acad. inside. of Ukraine. - Kyiv, 2005, 205 p.

${ }^{5}$ Kostytsky V. Ecology of the transitional period: Law, State, Economy (Economic and Legal Mechanism of Environmental Protection in Ukraine). Institute for Legislative Predictions and Legal Expertise. K.: EUSMEU SME SME, 2003, 772 p. (Series "Ecological Library”; № 5)
} 
Thus, the phenomenon of higher education as an objective social phenomenon is inseparable from the realization of the right to higher education, which denotes the scope of individual personality opportunities to acquire such a complex of diverse knowledge, skills, collectively designated in society and legitimized (officially recognized) by the State as the Higher Education.

There are different conceptual approaches to the definition of the right to higher education and the specifics of its legal support in the legal literature. But all of them are in one way or another dependent on the conceptual view of different scholars of the content and features of the right to education as basic, initial, original. We join the opinion of scholars who believe that the right to education has complex structure and includes a number of relatively independent rights, including the right to higher education ${ }^{6}$.

The right to higher education should be understood as a Governmentguaranteed opportunity for a person who already has the necessary level of basic education to obtain professional knowledge, skills, competences and their official recognition in order to meet the needs of society at a higher educational institution or scientific organization in accordance with established educational programs and standards and the state in training highly qualified specialists, as well as individuals in the intellectual, cultural and moral development with the bank of ecological knowledge of the acquired skills and knowledge implementation ${ }^{7}$. The point of view of the Ukrainian researcher M.O. Rusyn, which defines the right to higher education as the

(Library of the magazine "Small and Medium Business"); Kostytsky V. Organization of Continuous Environmental Education. Collection: Geographical Aspects of Volyn Resource Management. Lutsk, February 14-16, 1991, Lutsk, 1991; Kostytsky V. Environmental Law of Ukraine: [textbook]: 2 books. Drohobych: Circle, 2013, 363 p.; Libanova E. Social stratification of Ukrainian society: an attempt at statistical definition and measurement. Ukrainian Society. 2003, № 1 (2), pp. 146-164.

${ }^{6}$ Zagorodniy S. Contract on vocational training in higher education: author. diss. ... Cand. lawyer. Sciences: 12.00.03 - Civil Law, Family Law, Civil Procedure, Private International Law. Kharkiv. nat. un-t inside. affairs. - Kharkiv, 2007, 20 p.; Myshenko S. The right to higher education in Russia and Germany (comparative legal study): Author's abstract. diss. ... Cand. lawyer. of sciences. Specialty 12.00.02 - Constitutional Law; constitutional litigation; municipal law / S.A. Myshenko; Federal State Budget Educational Institution of Higher Professional Education "Baikal State University of Economics and Law". Irkutsk, 2015, 20 p.; Rusin M. The Right to Higher Education and its Constitutional Support. Comparative and analytical law, 2016, № 5, pp. 234-237.

${ }^{7}$ Todyka $\mathrm{Yu}$. The constitutional and legal status of a person and a citizen in Ukraine. Monograph. Kiev: View, In Yure House, 2004, 368 p.; Shevchuk S. The Concept of State Positive Duties in the Practice of the European Court of Human Rights. Law of Ukraine, 2010, № 2, pp. 55-64; Kostytsky V. Organization of Continuous Environmental Education. Collection: Geographical Aspects of Volyn Resource Management. Lutsk, February 14-16, 1991, Lutsk, 1991. 
legal personality of a person in the acquisition of knowledge, skills, competences etc. in higher educational institution, which correspond to the qualification of a specialist of a higher educational certain level in the relevant field of knowledge and determined by state standards ${ }^{8}$.

Hence, the noted constitutional right consists, in her opinion, of the following eligibilities: 1) the right to higher education funded by budgetary rather than own funds; 2) the right to receive scholarships and other forms of financial support; 3 ) the right to use libraries and information funds free of charge; 4) the right to use university's infrastructure free of charge; 5) the right to provide housing in a hostel free of charge or for a minimal fee'.

In our view, the outlined tendency in the legal literature to "split" the right to higher education into a number of eligibilities objectively has some heuristic potential, although some eligibilities need additional justification. However, the content structuring of the right to higher education makes it impossible to fully comprehend its specificity, not from the inside, but from the outside, namely in the system of other constitutional rights and freedoms of human and citizen. From this point of view, clarification of the essence of the right to higher education will be facilitated by: 1) clarification of the public or private nature of this right; 2) clarification of its relation with natural and positive human rights; 3) clarification of its relation with other environmental, social, economic and cultural rights; 4) study of its relationship with state activities, including the field of environmental protection and features of its implementation ${ }^{10}$.

In modern legal science there is no explicit and well-established conceptual approach to addressing the issues raised above. In particular, in discussions around the nature of the right to higher education - in terms of its affiliation with natural or positive rights - we consider a heuristically unacceptable and low-perspective position, according to which this right belongs exclusively to one or another group of rights, mostly to the category

${ }^{8}$ Rusin M. The Right to Higher Education and its Constitutional Support. Comparative and analytical law, 2016, № 5, pp. 234-237; Melnychuk O. Constitutional and legal support of the right to education in Ukraine in the context of European experience. dis. ... Doc. lawyer. Sciences Specialty 12.00.02 - Constitutional Law; municipal law / OF Melnychuk; Institute of State and Law. V.M. Koretsky NAS of Ukraine, Kyiv, 2015, 459 p. P. 236.

${ }^{9}$ Shapoval R. The human and citizen constitutional right to education in Ukraine. UR1: www.nbuv.gov.ua/portal/soc_gum/pib/2011_1/PB-1/PB-1_5.pdf. P. 7; Bonyak V. The human and citizen constitutional right to education and its support in Ukraine: Dis. ... Cand. lawyer. Sciences: 12.00.02 / V.O. Bonyak; Nat. Acad. inside. of Ukraine. Kyiv, 2005, 205 p. P. 5-6.

${ }^{10}$ Lysenko M. Innovative paradigm of higher education of Ukraine in the conditions of transition to the information society. Author's abstract diss. ... Cand. philosopher. of sciences. Specialty 09.00.10 - Philosophy of Education / M.V. Lysenko; National Technical University of Ukraine "Kyiv Polytechnic Institute". Kyiv, 2013, 19 p. 
of natural rights of the individual. Although, it is really hard to deny that everyone has a right to education since birth. Moreover, when it comes to knowledge related to the environment in the professional field and in life in general.

Likewise, from birth, everyone has the opportunity to pursue higher education after completing the secondary educational level, or even several higher education, which depends solely on the will of the individual. At the same time, we believe that in the modern world the right to higher education, despite its historically (genetically) natural (and therefore inalienable) character, has nevertheless undergone significant positivization at the levels of national and international legal documents. This is confirmed by the regulations documented particular in: Article 26 of the Universal Declaration of Human Rights (1948), Article 2 of Protocol I to the European Convention for the Protection of Human Rights and Fundamental Freedoms (1950), Articles 13, 14 of the International Covenant on Economic, Social and Cultural Rights (1960), Articles 3, 4 Convention on the Elimination of Discrimination in Education (1960), Article 5 of the International Convention on the Elimination of All Forms of Racial Discrimination (1965), Article 10 of the Convention on the Elimination of All Forms of Discrimination against Women (1979), Articles 28, 29 Convention on the Rights of the Child (1989), Article 43 of the International Convention for the Protection of the Rights of All Migrant Workers and Members of Their Families (1990), Article 14 of the EU Charter of Fundamental Rights (2000), Article 24 of the Convention on the Rights of Persons with Disabilities (2006), etc. ${ }^{11}$

\section{Environmental content of the right to higher education}

If classical human rights, also known in the theory of law as first generation rights, were largely aimed at restricting the State power ${ }^{12}$, then the right to higher education, like other educational rights, belongs to the positive, legally binding state rights (the so-called second generation rights), because for its realization it objectively requires the whole complex of actions of the state in to the person of its competent authorities in order to ensure the

${ }^{11}$ Krasnyakov E. International legal acts on education and its influence on the formation of state policy in the field of education of Ukraine. Viche, 2012, № 14. URL: http://www.viche.info/ journal / 3215 /; Pavlyukh O. The right to education: international and national dimension (in the context of the analysis of international treaties and national regulatory acts). Uzhgorod National University Scientific Bulletin, 2014. Pravo Series,Volume 24, Volume 4, pp. 178-181.

${ }^{12}$ Shevchuk S. The Concept of State Positive Duties in the Practice of the European Court of Human Rights. Law of Ukraine, 2010, № 2, pp. 54-55; Todyka Yu. The constitutional and legal status of a person and a citizen in Ukraine. Monograph. Kiev: View, In Yure House, 2004, 368 p., P. 7-8; Kostytsky V., Koban O. Limitation of the Legislature and the Judiciary: A Monograph, Kyiv, “ArtEk Publishing House, 2017, 228 p., P. 27-39. 
quantify of this right. After all, as the well-known Ukrainian constitutionalist S.V. Shevchuk spoke: "upon closer examination of the modern state's role in the realization of fundamental rights and freedoms, it becomes clear that their theoretical distinction, caused by certain contradictions between liberalism and communism, no longer meets the requirements of today. This is due to the fact that all fundamental rights are regarded as positive, as they depend on the state's actions to implement and protect them, and all the rights that are legally enforced become positive. That is, the classical liberal idea that the negative rights correspond to the negative obligation of the State not to interfere with their implementation, is modified by the positive obligation of the State regarding its implementation and guarantee"13.

This regulation is particularly relevant in the context of considering the environmental content of the right to higher education. We believe that in favor of adopting the statement about the mixed - naturally positive - nature of the right to higher education in modern conditions suggests the features of this right as the dependence of its realization on the state policy and socio and economic development of the country, its evolutionary character, as well as programmatically - the purpose of mutual responsibilities of the state and the individual in the higher education ${ }^{14}$. Finally, the "positivization" of the subjective right to higher education is facilitated by its contemporary interpretation as a public-private, not exclusively private law phenomenon, which must take into account the mechanism of its state support ${ }^{15}$. Thus, according to the Ukrainian researcher, O.F. Melnychuk, "the right to education reflects the balance of public and private interests"16. Obviously, this thesis is fully applicable to the field of higher education and its corresponding law.

${ }^{13}$ Shevchuk S. The Concept of State Positive Duties in the Practice of the European Court of Human Rights. Law of Ukraine, 2010, № 2, p. 57; Todyka Yu. The constitutional and legal status of a person and a citizen in Ukraine. Monograph. Kiev: View, In Yure House, 2004, 368 p.

${ }_{14}$ Bell D. The Future Post-Industrial Society: The Experience of Social Forecasting. Moscow: Academia, 1999, 783 p.

${ }^{15}$ Libanova E. Social stratification of Ukrainian society: an attempt at statistical definition and measurement. Ukrainian Society. 2003, № 1 (2), pp. 146-164.; Todyka Yu. The constitutional and legal status of a person and a citizen in Ukraine. Monograph. Kiev: View, In Yure House, 2004, 368 p.; Lysenko M. Innovative paradigm of higher education of Ukraine in the conditions of transition to the information society. Author's abstract diss. ... Cand. philosopher. of sciences. Specialty 09.00.10 - Philosophy of Education / M.V. Lysenko; National Technical University of Ukraine "Kyiv Polytechnic Institute". Kyiv, 2013, 19 p.

${ }^{16}$ Melnychuk O. Constitutional and legal support of the right to education in Ukraine in the context of European experience. dis.... Doc. lawyer. Sciences Specialty 12.00 .02 Constitutional Law; municipal law / of Melnychuk; Institute of State and Law. V.M. Koretsky NAS of Ukraine, Kyiv, 2015, 459 p. P. 92. 
Therefore, we can assert the mixed nature of the right to higher education, which undergoes substantial legal legitimation and positivization in modern society. This approach to this right is also facilitated by the understanding of the phenomenon of higher education itself as a public value, a public good ${ }^{17}$.

In the context of constitutional protection of human rights, we believe that education is an integral part of virtually all human and citizen rights, since without a sufficient level of intellectual development, competences, skills, knowledge, the realization and guarantee any right or civil liberty are impossible. Thus, there is a clear socio and legal relationship between the realization of the right to education, including higher education, and the proper realization of a whole set of other constitutional human and citizen rights. So, A. Melnychuk concludes that "There is a close interaction between the right to education and other constitutional rights, which is expressed in their interdependence, guaranteeing one right by another. Usually, this relationship is so strong that it is sometimes impossible to give preference to one of the rights by determining the level of fulfillment of the guarantee mission over the other" ${ }^{, 18}$. Without the realization of this right, it is impossible to exercise other constitutional rights ${ }^{19}$. For example, the realization of the right to higher education is closely linked to the realization of other constitutional (personal, political, social and cultural) rights of the individual, in particular such as: the right to a decent life (the right to a decent standard of living); the right to work, the right to rest, the right to freedom of literary, artistic, scientific and technical creativity, the right to objects of intellectual property, the right to participate in the management of public affairs, the right to information, the right to a safe and healthy environment etc. The exercise of many of these rights, according to A. Melnychuk, it would be ineffective without the realization the right to education $^{20}$. Beyond this right, it is difficult to exercise the right to use the

${ }^{17}$ Shapoval R. The human and citizen constitutional right to education in Ukraine. URl: www.nbuv.gov.ua/portal/soc_gum/pib/2011_1/PB-1/PB-1_5.pdf.; Bonyak V. The human and citizen constitutional right to education and its support in Ukraine: dis. ... Cand. lawyer. Sciences: 12.00.02 / V.O. Bonyak; Nat. Acad. inside. of Ukraine. - Kyiv, 2005, 205 p.

${ }^{18}$ Melnychuk O. Constitutional and legal support of the right to education in Ukraine in the context of European experience. dis.... Doc. lawyer. Sciences Specialty 12.00 .02 Constitutional Law; municipal law / OF Melnychuk; Institute of State and Law. V.M. Koretsky NAS of Ukraine, Kyiv, 2015, 459 p. P. 130.

${ }^{19}$ Shapoval R. The human and citizen constitutional right to education in Ukraine. URl: www.nbuv.gov.ua/portal/soc_gum/pib/2011_1/PB-1/PB-1_5.pdf.

${ }^{20}$ Melnychuk O. Constitutional and legal support of the right to education in Ukraine in the context of European experience. dis.... Doc. lawyer. Sciences Specialty 12.00 .02 Constitutional Law; municipal law / OF Melnychuk; Institute of State and Law. V.M. Koretsky NAS of Ukraine, Kyiv, 2015, 459 p. P. 162. 
results of scientific progress and the right to choose work ${ }^{21}$. In many cases, having a higher education qualification is a necessary prerequisite for the occupation of many socially important positions and social roles in modern society, including the posts of judges, prosecutors, attorneys, notaries, civil servants, officials of local governments, etc ${ }^{22}$. After all, the acquisition of a higher education person is an additional factor in the formation of a meaningful life position, an adequate level of awareness of the course of social processes, which makes it possible to adapt it in difficult or unfavorable environmental and socio-economic conditions, contributes to active creative behavior. Therefore, higher education becomes a major tool for the creation and multiplication of human capital ${ }^{23}$.

An extensive network of higher educational institutions, as well as other educational institutions, aims to promote the right of citizens of Ukraine to higher education (part one of Article 1 of the Law of Ukraine on Higher Education $^{24}$ ) on the basis of accessibility for every citizen of all forms and types of educational services that provided by the State; equality of conditions of each person for full realization of his abilities, talent, comprehensive development; continuity and diversity of education; (Article 6 of the Law of Ukraine "On Education" 25 ). It is clear that in view of such prolonged delay in the adoption of the Law of Ukraine "On environmental education" it is possible to include provisions on the ecological content of higher education and to take into account the environmental and environmental legal minimum level of the labor in the process of employment and change of position and profession.

${ }^{21}$ Zagorodniy S. Contract on vocational training in higher education: author. diss. ... Cand. lawyer. Sciences: 12.00.03 - Civil Law, Family Law, Civil Procedure, Private International Law. Kharkiv. nat. un-t inside. affairs. - Kharkiv, 2007, 20 p.; Bonyak V. The human and citizen constitutional right to education and its support in Ukraine: Dis. ... Cand. lawyer. Sciences: 12.00.02 / V.O. Bonyak; Nat. Acad. inside. of Ukraine. Kyiv, 2005, 205 p.

${ }^{22}$ Bonyak V. The human and citizen constitutional right to education and its support in Ukraine: dis. ... Cand. lawyer. Sciences: 12.00.02 / V.O. Bonyak; Nat. Acad. inside. of Ukraine. Kyiv, 2005, 205 p. P. 74.

${ }^{23}$ Libanova E. Social stratification of Ukrainian society: an attempt at statistical definition and measurement. Ukrainian Society. 2003, № 1 (2), pp. 146-164; Lysenko M. Innovative paradigm of higher education of Ukraine in the conditions of transition to the information society. Author's abstract diss. ... Cand. philosopher. of sciences. Specialty 09.00.10 - Philosophy of Education / M.V. Lysenko; National Technical University of Ukraine "Kyiv Polytechnic Institute". Kyiv, 2013, 19 p.

${ }^{24}$ On the Higher Education: Law of Ukraine of 01.07.2014 No. 1556-VII // Bulletin of the Verkhovna Rada of Ukraine, 2014, № 37-38, Art. 2004.

${ }^{25}$ On education: Law of Ukraine of May 23, 1991 No. 1060-XII // Bulletin of the Verkhovna Rada of Ukraine, 1991, № 34, Art. 451. 


\section{CONCLUSIONS}

According to this analysis, the subjective right of a person to higher education is an element of the broader content of the right to education, encompassing the elements of environmental and environmental legal education. Such law has a mixed (natural and positive) nature, combines private and public law components in its content, provides for a high level of public and state recognition, including legitimation at the level of positive legislation, and above all at the constitutional level, which makes it possible its enjoyment of other environmental, social, economic and cultural rights.

\section{SUMMARY}

The Article deals with the research of the main issues of the environmental component of the essence and contents of the right to higher education. Leading scientific and theoretical approaches to defining the right to higher education as a set of subjective legal capacity of a person are outlined. The place and role of the right to higher education in the system of subjective human and citizen rights are considered. The essence of the right to higher education clarifies by the determination of the mixed (public-private) nature of this right and its relationship with natural and positive human rights. The research focused on the fact that the enjoyment of other environmental, social, economic and cultural rights depends on the realization of a person's right to higher education. The aspects of interconnection of environmental component of the right to higher education with state activity in the environmental protection are investigated. Suggestions for taking into account prof. V. Kostytsky on the environmental component of vocational education, the continuous environmental education and environmental education support, taking into account the environmental and environmental legal minimum level of knowledge as a condition of appointment to a position and promotion in a position, the need to approve the draft law of Ukraine "On Environmental Education" developed in 1991 and to address this issue - to amend the educational legislation of Ukraine accordingly.

\section{REFERENCES}

1. Kostytskyi V. Ecology of the transitional period: Law, State, Economy (Economic and Legal Mechanism of Environmental Protection in Ukraine). Institute for Legislative Predictions and Legal Expertise. K.: EUSMEU SME SME, 2003, 772 p. (Series "Ecological Library"; № 5) (Library of the magazine "Small and Medium Business").

2. Kostytskyi V. Environmental Law of Ukraine: [textbook]: 2 books. Drohobych: Circle, 2013, 363 p. 
3. Libanova E. Social stratification of Ukrainian society: an attempt at statistical definition and measurement. Ukrainian Society. 2003, № 1 (2), pp. 146-164.

4. Bell D. The Future Post-Industrial Society: The Experience of Social Forecasting. Moscow: Academia, 1999, 783 p.

5. Zagorodniy S. Contract on vocational training in higher education: author. diss. ... Cand. lawyer. Sciences: 12.00.03 - Civil Law, Family Law, Civil Procedure, Private International Law. Kharkiv. nat. un-t inside. affairs. Kharkiv, 2007, 20 p.

6. Myshenko S. The right to higher education in Russia and Germany (comparative legal study): Author's abstract. diss. ... Cand. lawyer. of sciences. Specialty 12.00.02 - Constitutional Law; constitutional litigation; municipal law / S.A. Myshenko; Federal State Budget Educational Institution of Higher Professional Education "Baikal State University of Economics and Law". Irkutsk, 2015, 20 p.

7. Rusin M. The Right to Higher Education and its Constitutional Support. Comparative and analytical law, 2016, № 5, pp. 234-237.

8. Krasnyakov E. International legal acts on education and its influence on the formation of state policy in the field of education of Ukraine. Viche, 2012, № 14. URL: http://www.viche.info/journal/3215/.

9. Pavlyukh $\mathrm{O}$. The right to education: international and national dimension (in the context of the analysis of international treaties and national regulatory acts). Uzhgorod National University Scientific Bulletin, 2014. Pravo Series, Volume 24, Volume 4, pp. 178-181.

10. Todyka $\mathrm{Yu}$. The constitutional and legal status of a person and a citizen in Ukraine. Monograph. Kiev: View, In Yure House, 2004, 368 p.

11. Shevchuk S. The Concept of State Positive Duties in the Practice of the European Court of Human Rights. Law of Ukraine, 2010, № 2, pp. 55-64.

12. Melnychuk O. Constitutional and legal support of the right to education in Ukraine in the context of European experience. dis. ... Doc. lawyer. Sciences Specialty 12.00.02 - Constitutional Law; municipal law / of Melnychuk; Institute of State and Law. V.M. Koretsky NAS of Ukraine, Kyiv, 2015, 459 p.

13. Shapoval R. The human and citizen constitutional right to education in Ukraine. URl: www.nbuv.gov.ua/portal/soc_gum/pib/2011_1/PB-1/PB1_5.pdf.

14. Bonyak V. The human and citizen constitutional right to education and its support in Ukraine: dis. ... Cand. lawyer. Sciences: 12.00.02 / V.O. Bonyak; Nat. Acad. inside. of Ukraine. - Kyiv, 2005, 205 p.

15. Lysenko M. Innovative paradigm of higher education of Ukraine in the conditions of transition to the information society. Author's abstract diss. ... 
Cand. philosopher. of sciences. Specialty 09.00.10 - Philosophy of Education / M.V. Lysenko; National Technical University of Ukraine "Kyiv Polytechnic Institute". Kyiv, 2013, 19 p.

16. On education: Law of Ukraine of May 23, 1991 No. 1060-XII // Bulletin of the Verkhovna Rada of Ukraine, 1991, № 34, Art. 451.

17. On the Higher Education: Law of Ukraine of 01.07.2014 No. 1556-VII // Bulletin of the Verkhovna Rada of Ukraine, 2014, № 37-38, Art. 2004.

18. Kostenko O. Culture and Legal - Countering Evil: A Monograph, Kiev: Attica, 2008, 352 p.

19. Podolska E. Education in the context of globalization: directions and mechanisms of reform implementation in Ukraine. Higher school, 2007, № 1, pp. 48-55.

20. Kostytskyi V. Organization of Continuous Environmental Education. Collection: Geographical Aspects of Volyn Resource Management. Lutsk, February 14-16, 1991, Lutsk, 1991.

21. Kostytskyi V., Koban O. Limitation of the Legislature and the Judiciary: A Monograph, Kyiv, “ArtEk Publishing House', 2017, 228 p.

Information about the authors: Tymoshenko M., PhD., Associate Professor, Vice-Rector of Private Higher Education Institution "European University" 16, Akademika Vernads'koho blvd., Kyiv, 02000, Ukraine ORCID: 0000-0003-2584-5731

Sukhodolska A., Candidate of Law, Senior Lecturer at the Pavlo Tychyna Uman State Pedagogical University, Researcher at the Taras Shevchenko Kyiv National University of Medical Law 60, Volodymyrska str., Kyiv, 01033, Ukraine ORCID: 0000-0002-5794-9167 